\title{
IMPLIKASI FILSAFAT PENDIDIKAN DALAM PENGEMBANGAN KURIKULUM PENDIDIKAN AGAMA ISLAM PERSPEKTIF KUNTOWIJOYO
}

\author{
Moch. Tolchah \\ mochtolchah@gmail.com
}

\begin{abstract}
The writing of this scientific paper is intended to study and analyze the concept of prophetic values from the Kuntowijoyo's perspective with the framework of educational philosophy. Then what are the implications for the development of the Islamic education curriculum? So, it is expected to be an alternative criterion for the development of an Islamic education curriculum in the future. The writing method is using library research, with analytical and critical descriptive approaches; data collection methods: documentary method, which is looking for data on Kuntowijoyo's thought concept about prophetic values in the works he produces. The data analysis is deductive, inductive, and contextual. The findings in this paper can be concluded: First: The term prophetic has a prophethood meaning. The prophetic values of Kuntowijoyo's perspective consist of the humanization values, liberation, and transcendence: 1) Humanization means humanizing humans, eliminating materiality, dependence, violence, and hatred from humans, by fighting three things, namely dehumanization, aggressiveness, and loneliness, 2) Liberation has the meaning of liberating, which has social significance 3) Transcendence has theological meaning; Second: The humanization value of Kuntowijoyo's perspective can be traced to the roots of his educational philosophy, namely finding his viewpoint on the educational philosophy of idealism, pragmatism, existentialism, progressivism, essentialism, and reconstructionism. The emphasis point on the liberation value of Kuntowijoyo's perspective can be seen in the views of the philosophical genres of Idealism, Realism, Pragmatism, Existentialism, Progressivism, Essentialism, and Reconstructionism. While the value of transcendence finds its ideal base in the educational philosophical genres of Idealism, Religious Neo-Scholasticism, and Essentialism; Third: The implication of Kuntowijoyo's perspective of prophethood values on the development of the Islamic Education curriculum is beside wanting the development of a comprehensive Islamic education curriculum in the future (containing a widely
\end{abstract}


comprehensive understanding), with coverage of divine values, human and social values in it, are also directed at developing a subject-centered curriculum. In terms of development, the components are objectives, materials, strategies, and evaluations.

Keyword : Implications, Kuntopwijoyo Prophetic Values, Curriculum

\begin{abstract}
Abstrak
Penulisan karya ilmiah ini dimaksudkan untuk mengkaji dan menganalisis konsep nilai-nilai profetik perspektif Kuntowijoyo dengan kerangka filsafat pendidikan, kemudian apa implikasinya bagi pengembangan kurikulum pendidikan agama Islam, sehingga diharapkan dapat menjadi sebuah alternatif kriteria bagi pengembangan kurikulum pendidikan agama Islam di masa depan. Metode penulisannya menggunakan penelitian pustaka (library research), dengan pendekatan deskriptif analitis dan kritis; metode pengumpulan datanya : metode dokumenter, yaitu mencari data mengenai konsep pemikiran Kuntowijoyo tentang nilai-nilai profetik dalam karya-karya yang dihasilkannya; sedang analisis datanya dengan deduktif, induktif dan kontekstual. Temuan dalam penulisan ini dapat disimpulkan : Pertama : Istilah profetik mempunyai makna kenabian. Nilai-nilai profetik perspektif Kuntowijoyo terdiri dari nilai humanisasi, liberasi dan transendensi : 1)Humanisasi berarti memanusiakan manusia, menghilangkan kebendaan, ketergantungan, kekerasan, dan kebencian dari manusia, dengan melawan tiga hal yaitu dehumanisasi, agresivitas, dan loneliness, 2)Liberasi mempunyai makna membebaskan, yang bersignifikansi sosial 3)Transendensi mempunyai makna teologis; Kedua : Nilai humanisasi perspektif Kuntowijoyo dapat dilacak akar-akar filsafat pendidikannya, yaitu menemukan titik pandangnya pada filsafat pendidikan Idealisme, Pragmatisme, Eksistensialisme, Progresivisme, Esensialisme, dan Rekonstruksionisme. Titik tekan nilai liberasi perspektif Kuntowijoyo dapat dilihat dalam pandangan aliran filsafat Idealisme, Realisme, Pragmatisme, Eksistensialisme, Progresivisme, Esensialisme, dan Rekonstruksionisme. Adapun nilai transendensi menemukan basis idenya dalam aliran filsafat pendidikan Idealisme, Neoskolatisisme Religius, dan Esesnsialisme.; Ketiga : Implikasi nilainilai profetik (kenabian) perspektif Kuntowijoyo terhadap pengembangan kurikulum Pendidikan Agama Islam adalah, selain menghendaki pengembangan kurikulum pendidikan agama Islam masa depan yang komprehensif (mengandung pengertian yang luas dan menyeluruh), dengan cakupan nilai-nilai ketuhanan, kemanusiaan, dan nilai-nilai sosial di dalamnya, juga diarahkan pada pengembangan kurikulum yang
\end{abstract}


berpusat pada mata pelajaran (subject matter centered). Dalam segi pegembangan komponennya adalah, tujuan, materi, strategi dan evaluasi.

Kata kunci : Implikasi, Nilai-nilai Profetik Kuntowijoyo, Pengembangan kurikulum

\section{Pendahuluan}

Dunia yang senantiasa berkembang, berkonsekuensi pada perubahan realitas, baik yang tampak ataupun tidak tampak. Umat Islam pun mau tidak mau, suka tidak suka harus mampu menyesuaikan diri atau berdinamisasi dengan perkembangan global yang ditandai dengan kemajuan ilmu pengetahuan dan teknologi serta industrialisasi yang massif. Transformasi (perubahan) sosial umat Islam guna menyelaraskan dengan tuntutan zaman, tentunya, harus tetap dalam bingkai ajaran Islam. Maka agama harus mampu menjawab persoalan-persoalan kontemporer yang muncul.

Relevansi penafsiran agama dalam merespon perubahan dunia yang begitu dahsyat menjadi sebuah tuntutan. Sebagaimana dilansir oleh Mun'im A. Sirry bahwa saat ini umumnya, agama yang kehilangan kemampuan untuk merespon secara kreatif perubahan sosial, kerap menampakkan wajah fundamentalistiknya. Jika agama gagal membimbing umatnya, maka agama akan memasung pengikutnya pada lembah kebingungan, kefrustasian, dan pada akhirnya memunculkan reaksi destruktif, konflik, dan kekerasan. Dengan kata lain, kesulitan dalam mengatasi perubahan sosial dapat menyebabkan agama kehilangan pengaruh dan relevansinya. ${ }^{1}$

Ilmu Sosial Politik (ISP) yang dicetuskan oleh Kuntowijoyo secara sengaja memuat kandungan nilai-nilai dari cita-cita perubahan yang diidamkan masyarakat. Nilai ini diderivasikan dari misi historis Islam sebagaimana yang terkandung dalam Al-Qur'an Surat Al-Imran ayat 110, yang artinya:

\footnotetext{
${ }^{1}$ Mun'im A. Sirry, Membumikan Peran Profetik Agama (2005) dalam qalam.or.id/index.php?aksi=lihat\&id=30\&pilih=news-26kss.
} 
"Kamu adalah umat terbaik yang dilahirkan untuk manusia, menyuruh kepada yang ma'ruf dan mencegah dari yang munkar dan beriman kepada Allah”2

Tiga muatan nilai sebagai karakterik ilmu sosial politik dari ayat di atas adalah: pertama, humanisasi (menyuruh kepada yang ma'ruf atau menegakkan kebaikan), kedua, liberasi (mencegah kemunkaran), dan ketiga, transendensi (beriman kepada Allah). 3

Humanisasi, dalam pandangan Kuntowijoyo dimaksudkan sebagai memanusiakan manusia, yaitu upaya menempatkan posisi manusia sebagai makhluk yang mulia sesuai dengan kodrat atau martabat kemanusiaannya.4 Berdasarkan pemahaman ini, maka konsep humanisasi Kuntowijoyo berakar pada humanismeteosentris, yaitu manusia harus memusatkan diri kepada Tuhan, tetapi tujuannya adalah untuk kepentingan manusia sendiri.5

Adapun liberasi yang dimaksud Kuntowijoyo adalah nilai-nilai yang memiliki tanggung jawab profetik untuk membebaskan manusia dari kekejaman kemiskinan, pemerasan kelimpahan, dominasi struktur yang menindas dan hegemoni kesadaran palsu. 6

Salah satu komponen yang sangat penting dalam pendidikan adalah kurikulum. Kurikulum sebagai acuan atau program untuk mencapai tujuan pendidikan berpengaruh besar dalam membentuk output pendidikan berkualitas. Begitu juga nilai-nilai yang tertanam dalam peserta didik juga bergantung pada nilai-nilai yang terkandung dalam kurikulum yang menjadi acuan. Terlebih lagi bila berbicara tentang Pendidikan Agama Islam, dimana penanaman nilai-nilai menjadi suatu hal yang dominan, yang akan berefek pada aspek afektif dan psikomotor sebagai wujud nyata kesalehan vertikal dan kesalehan horizontal dalam diri peserta didik.

\footnotetext{
${ }^{2}$ Tim, Al-Qur'an dan Terjemahnya (Surabaya: Depag RI dan Penerbit Al-Hidayah, 2002), 94.

${ }^{3}$ Kuntowijoyo, Paradigma Islam Interpretasi Untuk Aksi (Bandung: Mizan, 1993), 87.

${ }^{4}$ Ibid., 229.

${ }^{5}$ Ibid., 228-230.

${ }^{6} \mathrm{M}$. Fahmi, Islam Transendental: Menelusuri Jejak-jejak Pemikiran Islam Kuntowijoyo (Yogyakarta: Pilar Religia, 2005), 126.
} 
Penelitian ini dimaksudkan untuk mengkaji dan menganalisis konsep nilainilai profetik perspektif Kuntowijoyo dengan kerangka filsafat pendidikan, kemudian apa implikasinya bagi pengembangan kurikulum pendidikan agama Islam. Ditemukannya implikasi dari nilai-nilai profetik perspektif Kuntowijoyo terhadap pengembangan kurikulum pendidikan agama Islam ini diharapkan dapat menjadi sebuah alternatif kriteria bagi pengembangan kurikulum pendidikan agama Islam di masa depan.

\section{Konsep Pengembangan Kurikulum Pendidikan Agama Islam}

Pengembangan kurikulum (curriculum development) merupakan kegiatan untuk menghasilkan kurikulum baru melalui langkah-langkah penyusunan kurikulum atas dasar hasil penilaian yang dilakukan selama periode atau waktu tertentu. Hendyat Soetopo mengartikan pengembangan kurikulum sebagai perubahan dan peralihan total dari satu kurikulum ke kurikulum lain, yang terjadi dalam kurun waktu yang panjang. ${ }^{7}$

Beberapa pakar pendidikan memberikan pengertian pengembangan kurikulum, di antaranya sebagai berikut:

1. Menurut Oemar Hamalik, pengembangan kurikulum adalah perencanaan kesempatan-kesempatan belajar yang dimaksudkan untuk membina siswa atau peserta didik ke arah perubahan perilaku yang diinginkan dan menilai hingga dimana perubahan-perubahan tersebut telah terjadi pada diri siswa yang bersangkutan. ${ }^{8}$

2. Menurut Beane, Toepfer dan Allesia, pengembangan kurikulum adalah suatu proses di mana partisipasi pada berbagai tingkat dalam membuat keputusan tentang tujuan, tentang bagaimana tujuan direalisasikan melalui proses belajar mengajar dan apakah tujuan dan alat itu serasi dan efektif. ${ }^{9}$

\footnotetext{
${ }^{7}$ Hendyat Soetopo dan Wasty Soenanto, Pembinaan Dan Pengembangan Kurikulum (Jakarta: Bumi Aksara, 1993), 45.

8 Oemar Hamalik, Sistem Dan Prosedur Pengembangan Kurikulum Lembaga Pendidikan Dan Pelatihan, 40.

${ }^{9}$ Hendyat Soetopo dan Wasty Soenanto, Pembinaan Dan Pengembangan Kurikulum (Jakarta: Bumi Aksara, 1993), 38.
} 
3. Menurut Subandijah, pengembangan kurikulum adalah suatu proses merencanakan, menghasilkan suatu alat yang lebih baik, dengan didasarkan pada hasil penilaian terhadap kurikulum yang telah berlaku, sehingga dapat memberikan kondisi belajar mengajar yang lebih baik.

4. Menurut Hendyat dan Wasty, pengembangan kurikulum adalah kegiatan menghasilkan kurikulum baru melalui langkah-langkah penyusunan, pelaksanaan, dan penyempurnaan kurikulum tersebut atas dasar hasil penilaian yang dilakukan selama kegiatan pengembangan tersebut. ${ }^{10}$

Dari beberapa definisi di atas, penulis menyimpulkan bahwa pengembangan kurikulum merujuk pada kegiatan menghasilkan kurikulum. Kegiatan ini lebih bersifat konseptual daripada material. Yang dimaksud dalam kegiatan pengembangan ini ialah penyusunan, pelaksanaan, penilaian, dan penyempurnaan, yang selanjutnya melahirkan kurikulum baru sebagai hasil dari pengembangan yang dilakukan.

Dari penjabaran di atas, dapat disimpulkan bahwa pengembangan kurikulum Pendidikan Agama Islam dapat diartikan sebagai: kegiatan menghasilkan kurikulum pendidikan agama Islam, proses yang mengaitkan satu komponen dengan yang lainnya untuk menghasilkan kurikulum yang lebih baik, ${ }^{11}$ dan atau kegiatan penyusunan (desain), pelaksanaan, penilaian, dan penyempurnaan kurikulum. Kegiatan pengembangan kurikulum pendidikan agama Islam ini merupakan suatu proses yang kontinyu, berkesinambungan, merupakan suatu siklus yang menyangkut beberapa komponen kurikulum.

Para ahli berbeda pendapat dalam pembagian komponen kurikulum. Dalam pandangan Subandijah, kurikulum terdiri atas komponen pokok dan komponen penunjang. Komponen pokok terdiri atas komponen: tujuan, isi/ materi, organisasi/ strategi, media, dan proses pembelajaran. Sedangkan komponen penunjang terdiri dari komponen: sistem administrasi dan supervisi, pelayanan bimbingan dan penyuluhan, dan sistem evaluasi. ${ }^{12}$ Adapun dalam pandangan Hendyat dan Wasty,

\footnotetext{
${ }^{10}$ Ibid., 41.

${ }^{11}$ Subandijah, Pengembangan Dan Inovasi Kurikulum (Jakarta: PT. Raja Grafindo Persada, 1996), 36.

${ }^{12}$ Ibid., 4.
} 
komponen kurikulum terdiri dari komponen: tujuan, materi (isi dan struktur program), organisasi dan strategi, sarana, dan evaluasi. ${ }^{13}$

Menurut penulis, tidak ada perbedaan yang signifikan tentang komponen kurikulum dalam pandangan tokoh-tokoh di atas, hanya titik tekannya saja yang berbeda, apakah satu bagian itu dipandang sebagai bagian dari yang lain atau tidak. Dari pandangan di atas, penulis menyimpulkan, setidak-tidaknya terdapat empat komponen utama kurikulum, yakni: pertama, komponen tujuan: berisi tujuan-tujuan yang ingin dicapai oleh suatu proses pembelajaran, dalam hal ini pembelajaran pendidikan agama Islam; kedua, komponen materi/ isi: berisi pengetahuan, informasiinformasi, data, aktifitas-aktifitas, dan pengalaman-pengalaman yang merupakan bahan bagi penyusunan kurikulum yang isinya berupa mata pelajaran yang kemudian dimasukkan dalam silabus, dalam hal ini mata pelajaran pendidikan agama Islam; ketiga, komponen strategi: berisi metode atau cara menyampaikan materi dan bagaimana skenario pembelajaran itu berlangsung. Yang dimaksud di sini adalah metode dan skenario pembelajaran pendidikan agama Islam; keempat, komponen evaluasi: berisi metode atau cara melakukan penilaian dan pengukuran untuk mengetahui sejauh mana daya serap anak didik terhadap materi yang diberikan. Dalam hal ini adalah evaluasi pembelajaran pendidikan agama Islam.

Dari konsep pengembangan kurikulum di atas, berikut ini akan dikaji konsep kurikulum dipandang dari kacamata aliran filsafat pendidikan. Penentuan mazhab atau aliran filsafat pendidikan ini bersifat elektif yaitu dengan memilih mazhabmazhab yang dianggap telah masyhur, dan telah menjadi wacana umum dalam ranah kajian filsafat pendidikan. Mazhab-mazhab tersebut adalah Idealisme, Realisme, Neoskolatisisme Religius, Pragmatisme, Eksistensialisme, Progresivisme, Esensialisme, dan Rekonstruksionisme.

Setelah penulis menemukan titik pandang filsafat-falsafat tersebut tentang kurikulum, maka kajian kemudian dilanjutkan dengan mengkaitkannya dengan konsep pengembangan kurikulum pendidikan agama Islam. Pada bagian ini, akan dianalisis implikasi pandangan mazhab-mazhab filsafat tersebut tentang kurikulum

\footnotetext{
${ }^{13}$ Hendyat Soetopo dan Wasty Soenanto, Pembinaan, 26-38.
} 
terhadap pengembangan kurikulum pendidikan agama Islam, terutama pada aspek pengembangan empat komponennya, yakni tujuan, materi/ isi, strategi, dan evaluasi.

\section{Pandangan Filsafat Pendidikan tentang Kurikulum}

1. Filsafat Idealisme

Aliran ini menyatakan bahwa kebenaran adalah ide-gagasan, maka kurikulum harus disusun di seputar materi-materi kajian yang mengantarkan peserta didik bergelut langsung dengan ide-gagasan. ${ }^{14}$ Kemampuan rasional, sebagai inti idealisme menduduki posisi prioritas untuk dikembangkan. Kurikulum penganut idealisme menekankan pada kajian humanities, yaitu kajian tentang kemanusiaan dengan tujuan pengembangan kemampuan rasional (dataran akal pikir). Pengetahuan yang diajarkan di sekolah harus bersifat intelektual ${ }^{15}$, karena yakin bahwa akal manusia dapat memperoleh pengetahuan dan kebenaran sejati. Guru menempati posisi yang amat krusial, sebab gurulah yang meladeni murid sebagai contoh hidup dari apa yang kelak bisa dicapainya. Guru juga dapat menyelenggarakan diskusi sehingga ia dan para murid dapat menangkap ide-gagasan dari berbagai bacaan dan perkuliahan, kemudian membawanya ke dalam fokus pembicaraan yang lebih tajam. ${ }^{16}$

Seorang penganut idealisme, Immanuel Kant, menyatakan bahwa guru harus memandang anak sebagai tujuan, bukan sebagai alat. Ia juga memandang bahwa pengetahuan yang terbaik adalah pengetahuan yang dikeluarkan dari dalam diri siswa, bukan dimasukkan atau dijejalkan ke dalam diri siswa. ${ }^{17}$

2. Filsafat Realisme

\footnotetext{
${ }^{14}$ George R. Knight, Filsafat Pendidikan (terjemahan) (Yogyakarta: Gama Media, 2007), 79.

${ }^{15}$ Uyoh Sadulloh, Pengantar Filsafat Pendidikan (Bandung: Alfabeta, 2003), 102.

${ }^{16}$ George R. Knight, Filsafat, 80.

${ }^{17}$ Uyoh Sadulloh, Pengantar, 101.
} 
Penganut realisme menyatakan pandangannya tentang kurikulum, yaitu kurikulum harus menekankan materi pengajaran tentang dunia fisik yang diajarkan dalam suatu cara bahwa keteraturan yang mendasari alam ini adalah hal yang tak terbantahkan. ${ }^{18}$ Dalam hal metode pembelajaran, penganut realisme modern menyukai demonstrasi-demonstrasi (pemeragaan materi) di ruang kelas, karya wisata, dan penggunaan alat bantu audio-visual dalam situasi dimana karyawisata tidaklah praktis atau akan memakan banyak waktu. Menurut aliran ini, pelajar atau anak didik dipandang sebagai sebuah organisme hidup, yang melalui pengalaman inderawiyahnya dapat menangkap tatanan alam dunia ini dan kemudian sampai pada pergumulan langsung dengan 'realitas'.19 Kurikulum juga bersifat komprehensif, sedangkan guru adalah orang yang berpengetahuan ${ }^{20}$ dan dipandang sebagai pemberi informasi yang akurat menyangkut realitas kepada anak didik dengan cara yang paling efisien dan paling cepat.

\section{Filsafat Neoskolatisisme Religius}

Kurikulum menurut pandangan aliran ini menekankan pada materi kajian yang berkaitan erat dengan aspek-aspek intelektual dan spiritual dari kebudayaan. ${ }^{21}$ Selain itu, anak didik dipandang sebagai makhluk rasional yang memiliki potensi alamiah untuk menggapai kebenaran dan pengetahuan, serta sebagai makhluk spiritual yang dapat berhubungan dengan Tuhan. ${ }^{22}$ Adapun guru, dilihat sebagai seorang pemimpin spiritual, seorang yang berdisiplin mental dengan kemampuan mengembangkan rasio, ingatan, dan daya kemauan pada diri anak didiknya. ${ }^{23}$

4. Filsafat Pragmatisme

Materi pengajaran menurut aliran ini harus dipilih dengan melihat pada kebutuhan-kebutuhan subjek didik, maka kurikulum tidak boleh dibagi

${ }^{18}$ George R. Knight, Filsafat, 88.

${ }^{19}$ Ibid., 87.

${ }^{20}$ Uyoh Sadulloh, Pengantar, 113.

${ }^{21}$ George R. Knight, Filsafat, 102.

22 Ibid., 99.

${ }^{23}$ Ibid., 100-101. 
ke dalam bidang materi pengajaran yang membatasi dan tidak alamiah. Kurikulum harus dibangun atas dasar unit-unit yang alamiah (wajar) yang tidak menimbulkan persoalan dan pengalaman yang menekan pada subjek $\operatorname{didik}^{24}$

Aliran ini juga memandang pelajar sebagai subjek yang memiliki pengalaman, atau seorang individu yang mengalami, sehingga dapat menjadikan dirinya mampu menggunakan kecerdasannya untuk memecahkan situasi-situasi problematis. Adapun guru, dipandang sebagai pendamping subjek didik dalam pengalaman pendidikan karena seluruh aktivitas kelas setiap harinya menghadapi dunia yang berubah. ${ }^{25}$

Lebih lanjut, menurut aliran ini, subjek didik harus secara bertahap berangkat dari belajar atas dasar pengalaman-pengalaman langsung menuju ke metode-metode belajar atas dasar pengalaman orang lain. Dengan kata lain, kurikulum sekolah kalangan pragmatis lebih memperhatikan proses daripada muatan materi. ${ }^{26}$

5. Filsafat Eksistensialisme

Kurikulum menurut kaum eksistensialis adalah terbuka bagi perubahan karena konsepnya tentang kebenaran adalah selalu berkembang dan berubah. Kurikulum ideal adalah kurikulum yang memberi para siswa kebebasan individual yang luas dan mensyaratkan mereka untuk mengajukan pertanyaan-pertanyaan, melaksanakan pencarian-pencarian mereka sendiri, dan menarik kesimpulan-kesimpulan mereka sendiri. ${ }^{27}$ Oleh karena itu, subjek didik akan menjadi sebuah faktor penentu dalam penyeleksian materi pengajaran dalam kurikulum, yang lebih menekankan pada kajian humanities karena ia memberikan 'pencerahan' yang besar akan persoalan-persoalan berat eksistensi manusia. ${ }^{28}$

\footnotetext{
${ }^{24}$ Ibid., 121.

${ }^{25}$ Ibid., 119-120.

${ }^{26}$ Ibid., 123.

${ }^{27}$ Uyoh Sadulloh, Pengantar, 137.

${ }^{28}$ George R. Knight, Filsafat, 137-138.
} 
Menurut kalangan eksistensialis, pendidikan harus dapat mengembangkan individualitas dan kreativitas, karena selama ini pendidikan lebih menitikberatkan pada pembentukan anak didik yang bermental konsumeristis atau hanya menjadikan anak didik sebagai tenaga penggerak dalam mesin teknologi industrial dan birokrasi modern. ${ }^{29}$ Oleh karena itu, pendidikan harus membentuk anak didik yang memiliki kedirian individu untuk sampai pada realisasi yang lebih utuh, bahwa anak didik itu adalah subjek yang memilih, subjek yang bebas, dan subjek yang bertanggung jawab secara pribadi.

Sedangkan guru, menurut pandangan aliran ini bukanlah sosok yang melulu memperhatikan alih pengetahuan kognitif, tapi lebih dari itu, guru adalah sosok yang berkemauan membantu para subjek didik mengeksplorasi jawaban-jawaban yang mungkin. ${ }^{30}$

\section{Filsafat Progresivisme}

Kalangan progresif menempatkan subjek didik pada titik sumbu sekolah (child-centered). Mereka lalu berupaya mengembangkan kurikulum dan metode pengajaran yang berpangkal pada kebutuhan, kepentingan, dan inisiatif subjek didik. Jadi, ketertarikan anak adalah titik tolak bagi pengalaman belajar. $^{31}$ Imam Barnadib menyatakan bahwa kurikulum progresivisme adalah kurikulum yang tidak beku dan dapat direvisi, sehingga yang cocok adalah kurikulum yang "berpusat pada pengalaman”. 32

Sains sosial sering dijadikan pusat pelajaran yang digunakan dalam pengalaman-pengalaman siswa, dalam pemecahan masalah serta dalam kegiatan proyek. ${ }^{33}$ Disini guru menggunakan ketertarikan alamiah anak untuk membantunya belajar berbagai keterampilan yang akan mendukung anak

\footnotetext{
${ }^{29}$ Ibid., 135.

${ }^{30}$ Ibid., 136.

31 Ibid., 149.

${ }^{32}$ Imam Barnadib, Filsafat Pendidikan: Sistem \& Metode (Yogyakarta: Andi Offset, 1997), 36.

${ }^{33}$ Uyoh Sadulloh, Pengantar, 148.
} 
menemukan kebutuhan dan keinginan terbarunya. Akhirnya, ini akan membantu anak (subjek didik) mengembangkan keterampilan-keterampilan pemecahan masalah dan membangun 'gudang' kognitif informasi yang dibutuhkan untuk menjalani kehidupan sosial. ${ }^{34}$

Selain itu, kaum progresif juga menganggap subjek-subjek didik adalah aktif, bukan pasif, sekolah adalah dunia kecil (miniatur) masyarakat besar, aktifitas ruang kelas difokuskan pada praktik pemecahan masalah, serta atmosfer sekolah diarahkan pada situasi yang kooperatif dan demokratis. ${ }^{35}$

7. Filsafat Esensialisme

Agak berbeda dengan pandangan kaum progresif, kalangan esensialis menganggap bahwa sekolah seharusnya tidak terlalu berpusat pada keinginankeinginan para peserta didik, tetapi yang diperlukan peserta didik adalah pemerolehan pengetahuan tentang dunia ini melalui penguasaan materi ajar yang esensial dan dasariah. ${ }^{36}$

Kurikulum kaum esensialis menekankan pengajaran fakta-fakta, dimana materi-materinya merupakan dasar yang esensial bagi 'general education' yang diperlukan dalam hidup. Kurikulum juga berpusat pada mata pelajaran (subject matter centered). ${ }^{37}$

Menurut pandangan kaum esensialis, belajar adalah sebuah usaha keras yang menuntut kedisiplinan, dan guru adalah lokus (titik) otoritas ruang kelas. ${ }^{38}$ Sedangkan anak didik perlu mendisiplinkan diri untuk memusatkan perhatian pada tugas yang ada di depan mata, dan di sisi lain, guru adalah orang yang mengetahui apa yang dibutuhkan peserta didiknya untuk diketahui, dan sudah sedemikian kenal dengan tataran logis materi ajar dan cara penyampaiannya. Guru merupakan model contoh yang sangat baik untuk

\footnotetext{
${ }^{34}$ George R. Knight, Filsafat, 150.

${ }^{35}$ Ibid., 150-156.

36 Ibid., 179.

${ }^{37}$ Uyoh Sadulloh, Pengantar, 162.

${ }^{38}$ George R. Knight, Filsafat, 179-180.
} 
ditiru dan digugu. ${ }^{39}$ Metode yang dapat digunakan dalam proses pembelajaran menurut aliran ini adalah metode pemecahan masalah (problem solving). ${ }^{40}$

8. Filsafat Rekonstruksionisme

Menurut pandangan aliran ini, kurikulum harus mampu menumbuhkan keberanian peserta didik untuk mempertanyakan status quo dan untuk mengkaji isu-isu kontroversial dalam agama, masyarakat, ekonomi, politik, dan pendidikan secara kritis. ${ }^{41}$ Kajian dan diskusi kritis ini diharapkan dapat membantu para peserta didik agar mampu melihat ketidakadilan dan ketidakfungsian beberapa sistem dalam masyarakat sekarang ini dan akan membantu mereka mengembangkan alternatif-alternatif bagi kebijaksanaan konvensional.

Aliran ini juga memandang kurikulum merupakan subject matter yang berisikan masalah-masalah sosial, ekonomi, politik yang beraneka ragam, yang dihadapi umat manusia, termasuk masalah-masalah sosial dan pribadi. Isi kurikulum menekankan pada "sains sosial" dan proses penemuan ilmiah (inkuiri ilmiah) sebagai metode kerja untuk memecahkan masalah-masalah sosial. $^{42}$

Berdasarkan pandangan kaum rekonstruksionis, pendidikan formal (sekolah) dapat menjadi agen utama dalam rekonstruksi tatanan sosial. Maka dari itu, proses pendidikan tidak lain adalah sebuah upaya memunculkan kesadaran peserta didik terhadap persoalan-persoalan sosial dan mendorong mereka untuk secara aktif memberikan solusi. Maka metode-metode pengajaran harus didasarkan pada prinsip-prinsip demokratis yang bertumpu pada kecerdasan asali jumlah mayoritas untuk merenungkan dan menawarkan solusi yang paling valid bagi persoalan-persoalan umat manusia. ${ }^{43}$

\footnotetext{
${ }^{39}$ Uyoh Sadulloh, Pengantar, 163.

${ }^{40}$ Ibid., 164.

${ }^{41}$ George R. Knight, Filsafat, 190.

${ }^{42}$ Uyoh Sadulloh, Pengantar, 169.

${ }^{43}$ George R. Knight, Filsafat, 187-190.
} 


\section{Implikasi Filsafat Pendidikan dalam Pengembangan Kurikulum Pendidikan Islam Perspektif Kuntowijoyo}

\section{Filsafat Idealisme}

Dalam kaitannya dengan pengembangan kurikulum pendidikan agama Islam, tujuan pembelajaran pendidikan agama Islam diarahkan pada upaya pendayagunaan potensi akal-pikir anak didik secara maksimal dengan harapan agar diperoleh penguatan doktrin-doktrin keagamaan yang sudah tertanam dalam diri anak didik, mengembangkan bakat atau kemampuan dasar di bidang pendidikan agama Islam serta kebaikan sosial.

Materi dalam kurikulum pendidikan agama Islam masa depan hendaknya lebih memberi porsi pada persoalan-persoalan humanities atau kajian-kajian kemanusiaan. Karena bertitik tekan pada pendayagunaan potensi akal-pikir, maka strategi atau skenario pembelajaran pendidikan agama Islam juga harus diperkaya dengan metode yang bervariasi seperti diskusi atau debat, dan menuntut penyampaian materi pendidikan agama Islam yang tidak terlalu tekstualis, tapi lebih merangsang daya nalar. Artinya, pendekatan rasional dipilih dalam penyampaian doktrin-doktrin ajaran Islam.

Guru pendidikan agama Islam dalam skenario pembelajaran selain berfungsi sebagai figur bagi anak didik, juga harus mampu menjadi mitra yang membantu anak didik dalam menemukan dan menggali gagasangagasan baru. Disini guru berperan sebagai fasilitator yang mengarahkan siswa agar dapat menemukan pengetahuan-pengetahuan baru. Pola pembelajaran pendidikan agama Islam lebih mengutamakan proses daripada hasil semata, sehingga berorientasi pada membelajarkan siswa (student oriented). Metode diskusi atau dalam pandangan Power (1982: 89) adalah metode dialektika, dipandang efektif dalam mengeksplorasi (menggali dan memunculkan) ide-gagasan dari peserta didik, serta akan semakin meningkatkan potensi akal pikirnya. Tapi metode lain yang juga dipandang efektif dapat juga diterapkan. 
Adapun teknik evaluasi menurut penulis yang cocok adalah menggunakan evaluasi acuan patokan (Criterian Referenced Evaluation) karena yang akan dites adalah prestasi belajar (achievement), dalam hal ini mengukur aspek kognitif. Pengukuran aspek ini dilakukan setelah siswa menuntaskan satu atau beberapa kompetensi dasar pendidikan agama Islam, dan juga pada akhir semester. Evaluasi ini diharapkan mampu mengukur adanya perubahan dalam diri siswa berupa kemampuan penguasaan terhadap materi dan kemampuan menjalankan tugas tertentu sesuai dengan tujuan pembelajaran. Alat evaluasi dapat berupa tes, baik tes formatif ataupun tes sumatif dengan bentuk tesnya uraian atau objektif.

Dari implikasi di atas, tampak bahwa prinsip yang hendaknya ditekankan dalam proses pembelajaran pendidikan agama Islam adalah prinsip learning to know (belajar untuk dan dengan cara mengetahui) untuk tercapainya kompetensi intelektual dan learning to be (belajar melalui dan untuk mengembangkan diri, keyakinan sebagai makhluk Allah SWT yang mengabdi kepadanya) demi mencapai kompetensi personal.

2. Filsafat Realisme

Karena filsafat realisme lebih menekankan pada realitas dunia fisik dan dunia rohani, maka tujuan pembelajaran pendidikan agama Islam dapat diarahkan pada terciptanya kemampuan anak didik untuk mampu menyesuaikan diri dalam kehidupannya dan memiliki tanggung jawab sosial. Kurikulum pendidikan agama Islam juga harus bersifat komprehensif (mengandung pengertian yang luas dan menyeluruh).

Adapun materi/ isi dalam pembelajaran pendidikan agama Islam menekankan pada pengalaman-pengalaman anak didik, bagaimana penerapan ajaran atau nilai-nilai Islam dalam kehidupan sehari-hari mereka. Sedangkan strategi pembelajaran pendidikan agama Islam diarahkan pada upaya membawa anak didik untuk peka terhadap realitas, baik realitas fisik maupun nonfisik. Ini dapat dilakukan dengan memberi kesempatan kepada peserta didik seluas-luasnya untuk terjun langsung demi memahami materi 
pendidikan agama Islam yang diberikan. Metode penyampaian materi harus logis dan psikologis. Karya wisata dan demonstrasi dapat menjadi salah satu metode pembelajaran. Misalnya, materi tentang zakat, akan cukup efektif bila siswa melakukan langsung praktik pengelolaan zakat tersebut sehingga siswa akan lebih cepat memahami makna dibalik ajaran zakat itu sendiri.

Teknik evaluasi pembelajaran pendidikan agama Islam yang cocok dapat berupa evaluasi acuan patokan (Criterian Referenced Evaluation) dan evaluasi acuan etik. Pemilihan acuan ini digunakan karena selain untuk mengukur aspek kognitif anak didik, juga untuk mengukur aspek afektif dan psikomotor. Aspek afektif dan psikomotor ini terkait erat dengan internalisasi dan aplikasi nilai-nilai keislaman dalam lingkungan masyarakat, artinya demi mewujudkan anak didik yang menjadi manusia "baik", bermoral, beriman dan bertaqwa. Adapun alat-alat evaluasinya dapat berbentuk tes, daftar cocok (check list), atau observasi eksperimental.

Dari implikasi terhadap tujuan pembelajaran di atas, tampak bahwa kompetensi personal dan kompetensi sosial menjadi titik tekan sebagai capaian dari proses pembelajaran pendidikan agama Islam. Kompetensi personal salah satunya menyangkut kemampuan bagaimana siswa memiliki penghayatan terhadap dirinya sebagai anggota masyarakat dan warga negara, menyadari kelebihan dan kekurangan yang dimiliki, sekaligus menjadikannya modal dalam meningkatkan dirinya sebagai individu yang bermanfaat bagi diri sendiri dan lingkungannya. Sedangkan kecakapan komunikasi dengan empati, sikap penuh pengertian dan komunikasi dua arah serta kecakapan dalam bekerja sama merupakan bagian dari kompetensi sosial.

3. Filsafat Neoskolatisisme Religius

Inti pandangan aliran ini adalah tentang Tuhan dan keimanan. Maka terkait dengan kurikulum pendidikan agama Islam, tujuan pembelajaran diarahkan pada upaya terbentuknya anak didik yang memegang teguh prinsipprinsip keimanan kepada Allah SWT. Selain itu juga bertujuan supaya anak didik memperoleh sebuah pemahaman bahwa mereka adalah makhluk 
spiritual, makhluk Allah yang dapat berhubungan dengannya dan harus mengabdi kepada-Nya.

Berbicara tentang Tuhan, tentu ini adalah persoalan akidah (keimanan). Dalam Islam, ini adalah yang pertama dan utama. Oleh karena itu, materi yang terkait dengan aspek keimanan (akidah) menjadi yang pertama dan utama diberikan kepada anak didik dalam proses pembelajaran, karena merupakan landasan (pondasi) ajaran Islam itu sendiri.

Skenario pembelajaran diarahkan pada upaya-upaya membantu mengembangkan kemampuan spiritual terutama keimanan dan intelektual anak didik. Pemberian materi keimanan, tentunya dengan argumentasi atau nalar yang logis dan tidak cenderung tekstualis, karena anak didik jenjang menengah berbeda tingkat intelektualitasnya (daya nalarnya) dengan jenjang di bawahnya. Metode diskusi atau debat, menurut penulis masih cukup efektif untuk memantapkan nalar keimanan peserta didik.

Karena terkait dengan keimanan kepada Allah SWT, maka evaluasi pembelajaran yang dipandang cocok dan dapat digunakan dalam pembelajaran pendidikan agama Islam adalah evaluasi acuan patokan (Criterian Referenced Evaluation) dan evaluasi acuan etik. Evaluasi acuan patokan digunakan untuk mengukur prestasi belajar siswa (ranah kognitif). Evaluasi acuan etik digunakan untuk mengukur kepribadian (personality) dan sesuai dengan tujuan pembelajaran, yakni meningkatkan keimanan kepada Allah SWT. Bentuk evaluasi dapat berupa tes (uraian, obyektif) dan non tes (observasi, chek list).

Dengan memperhatikan implikasi terhadap tujuan pembelajaran pendidikan agama Islam di atas, tampak bahwa prinsip belajar learning to be (belajar melalui dan untuk mengembangkan diri, keyakinan sebagai makhluk Allah SWT yang mengabdi kepada-Nya) demi mewujudkan kompetensi personal (pribadi) seorang anak didik, menjadi titik tekan dalam proses pembelajaran pendidikan agama Islam.

4. Filsafat Pragmatisme 
Jika menurut aliran ini pendidikan mempunyai fungsi sosial, maka dikaitkan dengan pendidikan agama Islam, tujuan pembelajarannya adalah bagaimana anak didik mampu memberi kontribusi dalam lingkungan tempat ia tinggal serta menambah pengalamannya untuk penemuan hal-hal baru dalam kehidupan sosial dan pribadinya.

Menurut kaum pragmatis, materi tidak boleh dibagi ke dalam bidang materi pengajaran yang membatasi, hendaknya demikian juga dalam materimateri pendidikan agama Islam. Menurut penulis, materi-materi pendidikan agama Islam dalam kurikulum pada hakikatnya merupakan satu kesatuan yang tidak terpisahkan, yang tergabung dalam tiga aspek, yakni akidah, syari'ah, dan akhlak. Meski terpisah dalam sub-sub mata pelajaran seperti Akidah Akhlak, Fiqh, Tarikh, dan lainnya, namun idenya tetap satu dan harus saling mendukung antar sub mata pelajaran. Pembelajaran akidah, didalamnya juga mengakomodir prinsip-prinsip syari’ah dan akhlak. Begitu juga sebaliknya. Materi puasa, misalnya, bukan hanya ditekankan sebagai bentuk keimanan kepada Allah SWT semata (akidah), tetapi juga terkandung pelajaran untuk selalu menjaga sikap dan tingkah laku kita dalam pergaulan (akhlak). Demikian juga antar sub materi atau pokok bahasan dalam satu mata pelajaran, harus ada keterkaitan. Materi-materi pendidikan agama Islam juga disusun berdasarkan pada pengalaman-pengalaman dan kebutuhan siswa dalam kehidupan sosial.

Dalam hal strategi pembelajaran di kelas, peserta didik perlu dibimbing oleh guru pendidikan agama Islam, bagaimana memecahkan berbagai problem dalam kehidupan kesehariannya, dengan perspektif ajaran Islam. Proses pembelajaran pendidikan agama Islam di kelas juga harus menekankan pada proses, bukan pada hasil semata. Lebih-lebih bahwa pendidikan agama Islam menitikberatkan pada penanaman nilai-nilai, etika dan moral. Tentunya, penanaman nilai membutuhkan proses yang tidak singkat. Metode yang digunakan, antara lain dapat berupa proses pembiasaan serta pemberian contoh atau keteladanan, dengan upaya mengaktifkan siswa. 
Penekanan pada proses, menuntut keaktifan siswa, jika meminjam pendapat Power (1982), yaitu melalui metode learning by doing (belajar sambil bekerja). ${ }^{44}$

Evaluasi yang dapat diterapkan dalam pembelajaran pendidikan agama Islam adalah evaluasi acuan etik. Evaluasi acuan ini untuk mengukur sejauh mana tujuan pembelajaran pendidikan agama Islam dapat tercapai, yakni pada aspek kepribadian (personality). Adapun alatnya, guru dapat menggunakan alat daftar cocok (check list) dan pengamatan (observasi), untuk mengukur sejauh mana telah terjadi perubahan perilaku siswa dalam kehidupan sosialnya.

Dari implikasi terhadap tujuan pembelajaran pendidikan agama Islam di atas, tampak bahwa prinsip belajar learning to live together (belajar melalui dan untuk hidup dalam kebersamaan) demi mewujudkan kompetensi sosial dalam diri siswa menjadi prioritas atau penekanan dalam pembelajaran pendidikan agama Islam.

5. Filsafat Eksistensialisme

Agar mampu bereksistensi, manusia harus mengoptimalkan segenap kemampuannya. Maka pembelajaran pendidikan agama Islam dapat diarahkan pada upaya mendorong setiap individu (anak didik) agar mampu mengembangkan potensinya untuk pemenuhan dirinya agar mampu hidup bermasyarakat dengan baik. Anak didik juga diharapkan memiliki sikap respek (rasa hormat) terhadap kebebasan untuk semua dalam kehidupan sosial.

Dari tujuan ini, tampak adanya penekanan pada prinsip belajar learning to live together, yakni belajar melalui dan untuk hidup dalam kebersamaan. Maka dari sini dapat dikatakan bahwa kompetensi sosial (kecakapan komunikasi dengan empati, sikap penuh pengertian dan komunikasi dua arah, serta kecakapan dalam bekerja sama) dalam diri siswa

${ }^{44}$ Uyoh Sadulloh, Pengantar, 133. 
menjadi harapan untuk dicapai setelah proses pembelajaran pendidikan agama Islam.

Jika kaum eksistensialis memandang penekanan kurikulum pada kajian humanities, maka dalam kurikulum pendidikan agama Islam seharusnya juga demikian. Dalam kurikulum pendidikan agama Islam, kajian humanities juga harus mendapatkan porsi tambahan untuk diberikan kepada peserta didik, karena pada akhirnya peserta didik kelak akan terjun ke masyarakat, menjadi bagian masyarakat, maka pengetahuan tentang bagaimana ia bermasyarakat menjadi penting. Dengan kata lain, persoalan hablu min al nas, atau bagaimana Islam mengatur hubungan sosial (sesama manusia) perlu menjadi titik tekan. Oleh karena itu, permasalahanpermaslahan sosial dapat menjadi basis materi pendidikan agama Islam, selain juga pengalaman-pengalaman pribadi guru dan anak didik yang dapat menjadi bahan refleksi dalam setiap proses pembelajaran pendidikan agama Islam.

Strategi pembelajaran pendidikan agama Islam dalam kelas juga harus mampu mengembangkan kreativitas peserta didik untuk menyelesaikan persoalan individu ataupun yang melingkupi masyarakatnya. Selain teknik pembelajaran berbasis permasalahan, metode diskusi atau debat masih dianggap cocok untuk diterapkan dalam proses pembelajaran. Kecakapan dalam menyelesaikan problem sosial, dapat meningkatkan pemahaman peserta didik, bahwa dalam pergaulan di masyarakat, mereka menyandang predikat sebagai wakil Allah SWT di muka bumi (khalifah fi al ardl).

Adapun evaluasi pembelajaran pendidikan agama Islam yang dapat digunakan adalah evaluasi acuan patokan (Criterian Referenced Evaluation) dan evaluasi acuan etik. Acuan patokan dipilih karena pembelajaran berbasis permasalahan menuntut penguasaan dan kemampuan daya nalar siswa (aspek kognitif) agar cerdas dan mampu menggali problematika dalam masyarakat. Sedangkan aplikasi iman yang berasal dari internalisasi nilai-nilai yang berbentuk kepedulian terhadap permasalahan di sekitarnya, masuk dalam 
aspek acuan etik dan dapat diukur dengan menggunakan alat chek list dan observasi.

6. Filsafat Progresivisme

Dalam pandangan kaum progresif, pembelajaran diarahkan pada pola pikir rasional. Maka, dalam pembelajaran pendidikan agama Islam, juga diarahkan pada pembentukan pola pikir rasional dalam diri siswa sehingga mereka menjadi cerdas, yang kemudian dapat memberi kontribusi pada anggota masyarakat lainnya.

Penguatan pola pikir rasional, merupakan aspek intelektual. Agar kompetensi intelektual ini dapat dicapai, maka prinsip belajar learning to know (belajar untuk dan dengan cara mengetahui) harus mendapatkan penekanan. Tapi bukan berarti kemudian bisa meningggalkan prinsip-prinsip belajar lainnya.

Materi pendidikan agama Islam, selain berisikan nilai-nilai pokok ajaran Islam, juga berbasiskan pada nilai-nilai sosial, nilai-nilai personal, dan juga mempertimbangkan minat-minat dan kebutuhan peserta didik dalam hubungannya dengan bidang-bidang kognitif, afektif, dan psikomotor. Materi pendidikan agama Islam juga bersifat fleksibel, artinya harus selalu peka terhadap realitas global serta perkembangan dan perubahan zaman yang terus menerus.

Subjek didik adalah aktif dan merupakan pangkal dari pembelajaran (dalam pandangan kaum progresif), maka proses pembelajaran pendidikan agama Islam dalam ruang kelas harus diupayakan pada pengaktifan peserta didik. Guru pendidikan agama Islam yang efektif memberi siswa pengalaman-pengalaman yang memungkinkan mereka belajar dengan melakukan kegiatan (learning by doing). Dalam mengkaji materi-materi pendidikan agama Islam, anak didik dirangsang oleh guru untuk aktif mengatasi persoalan, mengajukan pertanyaan, dan menyatakan pendapat atas gagasan-gagasannya. Pembelajaran berpusat pada siswa (student centered). Metode diskusi kelompok, dalam pandangan penulis akan cukup efektif 
dalam memupuk keberanian dan memunculkan keaktifan siswa dalam proses pembelajaran di ruang kelas.

Evaluasi pembelajaran pendidikan agama Islam yang cocok bisa menggunakan evaluasi acuan patokan (Criterian Referenced Evaluation) untuk mengukur ranah kognitif dengan asumsi, nantinya diharapkan bahwa siswa akan mempunyai kemampuan sesuai dengan apa yang dipelajari alias mampu menguasai materi dan mampu menjalankan tugas tertentu yang diberikan oleh guru. Bentuk tes, baik obyektif maupun uraian dapat digunakan sebagai instrumen (alat) evaluasi. Evaluasi tes ini, bisa berbentuk tes formatif ataupun tes sumatif.

7. Filsafat Esensialisme

Jika mengambil titik pandang dari aliran esensialisme, maka tujuan pembelajaran pendidikan agama Islam diarahkan pada upaya mempersiapkan anak didik untuk hidup atau menjalani kehidupan dalam lingkungan sosialnya. Anak didik harus memiliki rasa solidaritas sosial dan ikut berperan serta mewujudkan kesejahteraan umum. Pewarisan nilai-nilai luhur ajaran Islam oleh sosok guru juga menjadi titik tekan tujuan pembelajaran.

Dari tujuan pembelajaran di atas, aspek sosial tetap menjadi titik tekan. Tentu saja, tercapainya kompetensi sosial, yakni kecakapan komunikasi dengan empati, sikap penuh pengertian dan seni komunikasi dua arah serta kecakapan bekerja sama dalam masyarakat, menjadi harapan. Oleh karena itu, prinsip belajar learning to live together harus mampu diterapkan secara baik dalam proses pembelajaran pendidikan agama Islam.

Adapun tentang materi/ isi, maka kurikulum pendidikan agama Islam hendaknya berisi hal-hal yang bersifat mendasar yang ingin ditanamkan ke dalam diri peserta didik. Terutama nilai-nilai. Nilai-nilai penting (esensial) yang ingin ditanamkan kepada peserta didik selain nilai-nilai keimanan (doktrin-doktrin agama dalam kitab suci), adalah nilai kemanusiaan, dan nilai-nilai sosial. Nilai-nilai mendasar ini, tentunya akan berguna bagi peserta didik agar kelak dapat menjalankan fungsinya sebagai khalifah di muka bumi. 
Penanaman nilai, tentunya membutuhkan proses yang tidak singkat atau tidak instan. Salah satu cara efektifnya adalah dengan memberi contoh atau keteladanan dari sosok seorang guru pendidikan agama Islam bagi anak didiknya. Maka, metode yang dapat digunakan adalah pemberian contoh, keteladanan, pembiasaan, dan pendekatan persuasif atau mengajak siswa dengan cara yang halus dengan memberikan argumentasi dan prospek baik yang bisa meyakinkan anak didik. Tapi bukan berarti harus meninggalkan metode ceramah. Maka di sini tampak bahwa sosok guru merupakan lokus (titik) otoritas ruang kelas. Selain harus mampu meracik strategi pembelajaran yang tepat dan menarik, Guru pendidikan agama Islam juga harus punya kapasitas keteladanan yang lebih dibanding guru mata pelajaran lain, dan membekali dirinya dengan kemampuan intelektual yang tinggi. Dalam praktik skenario pembelajaran pendidikan agama Islam, inisiatif-inisiatif guru berperan besar.

Dalam segi evaluasi pembelajaran pendidikan agama Islam, ditekankan pada evaluasi acuan etik. Acuan ini dipilih karena berkenaan dengan upaya mengukur internalisasi dari nilai-nilai keimanan dan kemanusiaan pada siswa dan sejauh mana implementasi dari nilai-nilai keimanan itu dalam ranah sosial. Asumsi acuan ini berusaha untuk mengembangkan fitrah (aktualisasi) yang melekat pada diri peserta didik. Evaluasi acuan etik ini dalam pandangan penulis, relevan dengan tujuan pembelajaran, yakni menjadikan peserta didik sebagai manusia "baik", bermoral, beriman dan bertaqwa.

\section{Filsafat Rekonstruksionisme}

Dengan mendasarkan pada pandangan kaum rekonstruksionis, tujuan pembelajaran pendidikan agama Islam diarahkan pada upaya menanamkan pemahaman kepada siswa agar peka terhadap realitas sosial, mampu menggali problem-problem sosial, ketidakadilan dan penyimpangan yang terjadi dalam kehidupan sosial. Tujuan pembelajaran juga untuk melatih dan memberi 
pengalaman kepada anak didik supaya mampu memecahkan problematika sosial dalam perspektif ajaran dan nilai-nilai agama Islam.

Kemampuan menggali dan menemukan problem sosial membutuhkan kemampuan rasional/ daya pikir, dan agar mampu menyelesaikan problem tersebut dalam masyarakat diperlukan kecakapan dalam berkomunikasi dan bekerja sama dengan baik dengan angota-anggota masyarakat. Maka disini, siswa dituntut untuk mempunyai tidak hanya kompetensi intelektual dan personal, tapi juga kompetensi sosial dan vokasional. Pembelajaran pendidikan agama Islam dapat diarahkan pada upaya-upaya terbentuknya kompetensi-kompetensi tersebut.

Adapun materi kurikulum pendidikan agama Islam merupakan subject matter yang berisikan masalah-masalah sosial, ekonomi, politik yang beraneka ragam, yang dihadapi umat manusia, termasuk masalah-masalah sosial dan pribadi. Materi pendidikan agama Islam juga berisi persoalan sosial dan budaya yang dihadapi masyarakat, dan merupakan hal yang penting untuk disampaikan kepada anak didik. Maka, isi kurikulum (materi) pendidikan agama Islam hendaknya lebih meningkatkan porsi pada kajiankajian sosial dan budaya, demi menciptakan kesadaran dan daya kritis peserta didik terhadap situasi sosial yang ada di sekitarnya.

Dalam proses pembelajaran pendidikan agama Islam, Guru pendidikan agama Islam berperan sebagai project director, yang mampu memimpin dan mengarahkan transformasi, serta mampu menjadi agen perubahan, mempersoalkan ketidakadilan dalam masyarakat, dan bersama peserta didiknya berusaha membentuk masyarakat baru. Metode diskusi atau debat dalam kegiatan pembelajaran pendidikan agama Islam dapat digunakan untuk menyelesaikan permasalahan-permasalahan yang diberikan guru. Kegiatan pembelajaran juga tidak harus dilaksanakan di dalam kelas, tapi dapat dilaksanakan di segala tempat dan setting sesuai dengan karakteristik materinya. Maka, metode observasi dan terjun lapangan (learning by doing) dapat menjadi pilihan untuk diterapkan demi mengajak anak didik agar lebih 
peka terhadap realitas sosial, dan mampu menemukan ketidakseimbangan dalam sistem sosial tersebut, untuk selanjutnya berusaha dirumuskan caracara pemecahannya melalui scientific method (metode ilmiah). Metode ini diawali dengan mengidentifikasi masalah-masalah yang terkait dengan tematema yang diberikan guru, kemudian merumuskan hipotesis, dan dilanjutkan dengan melaksanakan penelitian di lapangan.

Bentuk evaluasi dalam pembelajaran pendidikan agama Islam yang dapat diterapkan adalah evaluasi acuan patokan (Criterian Referenced Evaluation) dan evaluasi acuan etik. Evaluasi acuan patokan digunakan untuk mengukur prestasi belajar (ranah kognitif), yakni kemampuan intelektualitas atau nalar siswa dalam menggali problem-problem sosial. Evaluasi acuan etik digunakan untuk mengukur/ mengetes kepribadian (personality), yakni sampai sejauh mana empati dan kepedulain siswa terhadap problematika sosial berupa ketidakadilan, penindasan, dan lainnya yang ada di sekitarnya. Evaluasi dapat berbentuk tes (baik tes uraian atau tes obyektif) dan non tes (daftar cocok/ check list, observasi). Evaluasi tes juga dapat berbentuk tes formatif ataupun tes sumatif. Laporan kerja praktik, sebagai salah satu jenis tagihan juga dapat diterapkan setelah anak didik selesai melakukan observasi dan terjun lapangan.

Menurut penulis, pendekatan CTL (Contextual Teaching and Learning) yang merupakan upaya mengkaitkan materi pelajaran dengan situasi dunia nyata/ konteks kehidupan sehari-hari (konteks pribadi, sosial, dan kultural) atau yang disimulasikan, sehingga siswa dapat menghubungkan antara pengetahuan yang diperolehnya dengan penerapannya dalam kehidupan sehari-hari sebagai anggota keluarga dan masyarakat, dapat diterapkan dalam proses pembelajaran pendidikan agama Islam.

Dari paparan tentang implikasi filsafat pendidikan terhadap pengembangan kurikulum pendidikan agama Islam di atas, tampak bahwa pengembangan kurikulum pendidikan agama Islam masa depan hendaknya selain mempertahankan karakteristiknya yang lebih mengutamakan pada upaya 
internalisasi nilai-nilai ajaran Islam (akidah, syari'ah, akhlak), juga hendaknya meningkatkan porsi pada aspek perubahan sosial sebagai tuntutan zaman. Maksudnya, meningkatkan porsi pada upaya penanaman nilai-nilai kemanusiaan dan sosial. Pendek kata, kandungan nilai-nilai Ilahiyah dan nilai-nilai insaniyah harus memiliki porsi yang seimbang dalam kurikulum pendidikan agama Islam agar selain mampu mewujudkan peserta didik yang memiliki iman dan taqwa yang kuat menghadapi perkembangan global dan kecenderungan dunia, juga memiliki rasa kepedulian sosial yang tinggi terhadap ketidakadilan dalam masyarakatnya dan mampu berpartisipasi aktif dalam pengembangan masyarakat menuju kemajuan yang dicita-citakan.

Demi terealisasinya tujuan-tujuan di atas, kurikulum pendidikan agama Islam dengan pendekatan rekonstruksi sosial berlandaskan tauhid dapat menjadi menjadi salah satu alternatif pengembangan kurikulum pendidikan agama Islam masa depan. Dalam pandangan penulis, kurikulum ini akan mampu mengakomodir tidak hanya nilai-nilai Ilahiyah, tapi juga nilai-nilai insaniyah dan nilai-nilai sosial. Dengan terakomodirnya nilai-nilai tersebut, diharapkan kurikulum pendidikan agama Islam akan mampu membentuk tidak hanya anak didik yang memiliki mental keimanan yang kuat, tapi juga cakap atau kreatif untuk selanjutnya mampu bertanggung jawab terhadap pengembangan masyarakatnya.

\section{Kesimpulan}

Istilah profetik mempunyai makna kenabian. Nilai-nilai profetik perspektif Kuntowijoyo terdiri dari nilai humanisasi, liberasi dan transendensi. Humanisasi berarti memanusiakan manusia, menghilangkan kebendaan, ketergantungan, kekerasan, dan kebencian dari manusia, dengan melawan tiga hal yaitu dehumanisasi (objektivasi teknologis, ekonomis, budaya, atau negara), agresivitas (agresivitas kolektif, dan kriminalitas), loneliness (privatisasi, individuasi). Liberasi mempunyai makna membebaskan, yang bersignifikansi sosial dengan tujuan membebaskan manusia dari kekejaman pemiskinan struktural, keangkuhan 
teknologi, pemerasan kelimpahan, dominasi struktur yang menindas, dan hegemoni kesadaran palsu. Transendensi mempunyai makna teologis, yakni ketuhanan, maksudnya bermakna beriman kepada Allah SWT. Transendensi bertujuan menambahkan dimensi transendental dengan cara membersihkan diri dari arus hedonisme, materialisme, dan budaya yang dekaden. Singkatnya, menghendaki manusia untuk mengakui otoritas mutlak Allah SWT.

Nilai humanisasi perspektif Kuntowijoyo dapat dilacak akar-akar filsafat pendidikannya, yaitu menemukan titik pandangnya pada filsafat pendidikan Idealisme, Pragmatisme, Eksistensialisme, Progresivisme, Esensialisme, dan Rekonstruksionisme. Inti pandangan dari mazhab-mazhab ini adalah tentang humanisme, dimana spiritualisme (bertitik tekan pada pemberdayaan jiwa dan akal manusia) menjadi bagiannya. Maksudnya, manusialah yang mengembangkan potensi kemanusiaannya sehingga mampu hidup dan memberi warna atau pengaruh pada lingkungan sekitarnya menuju perubahan yang lebih baik dan ideal.

Titik tekan nilai liberasi perspektif Kuntowijoyo dapat dilihat dalam pandangan aliran filsafat Idealisme, Realisme, Pragmatisme, Eksistensialisme, Progresivisme, Esensialisme, dan Rekonstruksionisme. Inti pandangannya menyatakan bahwa upaya-upaya perubahan dari suatu tatanan sosial, ekonomi, politik, dan lainnya yang tidak adil dan penuh penindasan, merupakan suatu keniscayaan yang harus mampu dilakukan oleh setiap individu dengan memaksimalkan aspek intelektualitasnya demi menuju suatu tatanan kehidupan yang adil, tanpa kesenjangan, penindasan dan hegemoni, serta menghargai nilainilai kemanusiaan. Adapun nilai transendensi menemukan basis idenya dalam aliran filsafat pendidikan Idealisme, Neoskolatisisme Religius, dan Esesnsialisme. Kesamaan titik pandangnya yaitu lebih memberikan porsi pada reposisi kedudukan Tuhan bagi manusia, yaitu sebagai otoritas mutlak, merupakan jiwa universal yang abadi, serta penguasa alam. Manusia sebagai bagian dari alam harus mendasarkan semua tindakannya pada perintah Tuhan yang telah mengatur alam dengan hukum-hukumnya. 
Implikasi nilai-nilai profetik (kenabian) perspektif Kuntowijoyo dalam pengembangan kurikulum pendidikan agama Islam adalah, selain menghendaki pengembangan kurikulum pendidikan agama Islam masa depan yang komprehensif, dengan cakupan nilai-nilai ketuhanan, kemanusiaan, dan nilai-nilai sosial di dalamnya, juga diarahkan pada pengembangan kurikulum yang berpusat pada mata pelajaran (subject matter centered). Dalam segi pengembangan komponennya adalah: Pertama, komponen tujuan : nilai-nilai profetik menghendaki, selain tujuan pembelajaran pendidikan agama Islam diarahkan pada pemantapan atau penguatan doktrin-doktrin keagamaan yang ada dalam kitab suci dengan mengoptimalkan nalar (rasio), juga bertujuan agar anak didik peka terhadap realitas sosial yang ada di sekitarnya, dengan berusaha menumbuhkan pola pikir kritis. Kedua, komponen materi/ isi : Nilai-nilai profetik menghendaki materi dalam pembelajaran pendidikan agama Islam lebih dikembangkan dan memberi porsi signifikan pada intelektualitas. Materi pendidikan agama Islam hendaknya tidak dibagi ke dalam bidang materi pengajaran yang membatasi, yang justru bisa mengaburkan makna pendidikan agama Islam itu sendiri. Selain itu, lebih memberi porsi pada persoalan-persoalan (problematika) kemanusiaan atau kajian humanities. Materi pendidikan agama Islam juga berisi pengalamanpengalaman siswa dan guru yang dianggap penting dan relevan sebagai bahan refleksi. Ketiga, komponen strategi (proses pembelajaran) : nilai-nilai profetik menghendaki strategi pembelajaran pendidikan agama Islam lebih dikembangkan agar mampu merangsang peserta didik untuk mendayagunakan potensi akalpikirnya secara maksimal, sehingga penyampaian materi pendidikan agama Islam hendaknya tidak terlalu tekstualis, tapi lebih merangsang daya nalar (rasio). Metode pembelajaran diarahkan pada learning by doing (belajar sambil bekerja), dengan mengutamakan teknik problem solving (penyelesaian masalah). Keempat, komponen Evaluasi:nilai-nilai profetik menghendaki evaluasi pembelajaran pendidikan agama Islam lebih dikembangkan, tidak hanya evaluasi acuan patokan (Criterian Referenced Evaluation) semata, tapi juga dengan menggunakan evaluasi acuan etik. 


\section{Daftar Pustaka}

Barnadib, Imam. 1997. Filsafat Pendidikan: Sistem \& Metode,Yogyakarta: Andi Offset.

Fahmi, M., 2005. Islam Transendental: Menelusuri Jejak-Jejak Pemikiran Islam Kuntowijoyo, Yogyakarta: Pilar Religia.

Hamalik, Oemar, 1993. Pengembangan Kurikulum Lembaga Pendidikan dan Pelatihan: Sistem dan Prosedur, Bandung: Trigenda Karya,.

Kuntowijoyo. 2007. Islam Sebagai Ilmu: Epistemologi, Metodologi, dan Etika, Yogyakarta: Tiara Wacana. , Paradigma Islam: .1993. Interpretasi Untuk Aksi, Bandung: Mizan,.

, Muslim Tanpa Masjid: Esai-Esai Agama, Budaya, dan Politik dalam Bingkai Strukturalisme Transendental, 2001. Bandung: Mizan.

, Dinamika Sejarah Umat Islam Indonesia. 1994. Yogyakarta: Shalahuddin Press dan Pustaka Pelajar.

, Identitas Politik Umat Islam. 1997. Bandung: Mizan.

Muhaimin. 2007. Pengembangan Kurikulum Pendidikan Agama Islam, Jakarta: Raja Grafindo Persada,.

Sirry, Mun'im A. Membumikan Peran Profetik Agama (2005) dalam qalam.or.id/index.php?aksi=lihat\&id=30\&pilih=news-26kss. 
Soetopo, Hendyat dan Wasty Soemanto. 1993. Pembinaan dan Pengembangan Kurikulum, Jakarta: Bumi Aksara.

Subandijah, Pengembangan Dan Inovasi Kurikulum. 1996. Jakarta: PT. Raja Grafindo Persada,.

Tim, Al Qur'an dan Terjemahnya. 2002. Surabaya: Depag RI dan Penerbit Al Hidayah. 